\title{
Chromosomal and biochemical assessments of six garlic clones
}

Gehan M. Anwar*, Abdeltawab M. Ata, Ahmed E. Abu Salha, Alzahraa A. Abdallah

Department of genetics, Faculty of Agriculture, Minia University, Egypt

*Corresponding author: gehan_ma@mu.edu.eg, gehan_ma@yahoo.com;Tel: + 01008998651.

\section{Article information}

Received: 11 January2021

Revised: 24 February2021

Accepted: 25 February2021

\section{Key words}

Garlic

Chromosomal aberration

Sat-chromosomes

Micro nuclei

Isozymes

\section{Abstract}

Garlic (Allium sativum L.) is a commonly used Allium crop worldwide. It might be expected that garlic would show some intraspecific variations because of its vegetative reproduction. The main goal of this study was to examine the chromosomal aberrations and the relationship between secondary constrictions and nucleolus organizing regions in six garlic clones. Moreover, the biochemical assessments of total protien, esterase and glutamate gxaloacetate transaminase (GOT) were also carried out. Different types of chromosomal aberrations such as (i.e.) chromosome gap, chromatid break, centromeric attenuation and end-to-end association were scored. Data showed that the highest percentage of chromosome gap (15\%) was observed in EGA 2 clone. The other structural aberrations were found in different percentages. According to the presence, number and position of the secondary constrictions (SC) and satellites (SAT), four different categories for six garlic clones studied could be identified. Nucleoli number at both interphase and prophase showed consederable differences among the six clones. For instance, percentage of nucleoli at interphase varied from $94 \%$ to $97 \%$ (one nuclelus) in Sids 40 and EGA4, respectively. No cells was detected at the prophase containing four nucleoli. A strong relationship was observed between existence of the structural chromosomal aberrations and numbers and position of some cytological markers such as satellites, secondary constrictions and nucleoli. No differences were founed among all studied cloves of the six garlic clones by using total protien, esterase and GOT. In the present work, the relationship between the assessed biochemical markers and the scored chromosomal aberrations couldn't be proved.

\section{Introduction}

Garlic is a diploid species $(2 \mathrm{n}=2 \mathrm{X}=16$ ) belonging to Allium genus of the Alliaceae family, order Asparagales. Collins and Kerns [1] reported that mutations in asexually propagated plants may conceivably play a role in the developing as well as adaptation of new varieties. Therefore, Koul et al. [2] confirmed that garlic has accumulated a lot of variation in various plant characteristics either through gene mutations or structural alterations of chromosomes. Good confirmations have been verified to declare that garlic karyotype is not noticeably recognized because of apomictic nature of its propagation and the accumulation of actual structural aberration [3 -11]. Chromosomal aberrations are common in garlic e.g. ten to forty chromosome translocations have been identified [7 \& 12]. Other structural aberrations such as chromosomal and chromatid bridges, chromatin stickiness, chromosomal breaks and fragments were also recognized [7 \& 9]. In Allium sativum, satellite and secondary constriction bearing chromosomes (SAT chromosomes) were unusually influenced by the structural abnormalities more often than the other chromosomes. SAT chromosome profiles could be employed as chromosomal marker and used to assign garlic clones [8 \& 13]. According to Ata et al. [11], five karyotype categories have been identified (Category $1=$ zero Sat-chromosome per cell, Category $2=$ one heteromorphic Sat-chromosome, Category $3=$ two heteromorphic Sat-chromosome, Category $4=$ three heteromorphic Sat-chromosome per cell and Category 5= four Sat-chromosome at two heteromorphic pairs. Likewise, it was difficult to define which chromosome of the 8 pairs could be called as SAT chromosomes because the secondary constrictions (SC) and the satellites (SAT) could be observed in all 8 chromosome pairs but with variable percentages. For instance, chromosome pair nos.5, 6 and 7 exhibited the highest percentages.

It is generally assumed that the presence of the secondary constrictions is an indication to the locations of the NORs. Miller and Brown [14] determined that the size of the secondary constrictions correlated definitely with the redundancy of the rRNA genes. However, it is abstruse whether the size of the achromatic secondary constrictions directly reflects the number of rRNA genes or the synthetic activity of rRNA per gene. Sato et al. [13] compared the results obtained by applying the silver staining technique, which is most widely used to identify specifically the NORs and the nucleoli [15] to the somatic chromosomes of A. sativum. They concluded that not all NORs are presented by the morphological appearance of secondary constrictions.

Acquaah [16] reported that isozymes (or isoenzyme) are powerful tool for assessing the variability of gene activity 
within and between populations of plants and animals. In garlic, total protein profiles and several izozymes such as alcohol dehydrogenase, esterase, glutamate oxaloacetate transaminase (GOT), peroxidase and phosphoglucoisomerase showed different patterns between clones, accessions and even in cultured cells $[3 ; 17-25]$. In addition, using these biochemical markers allowed dividend garlic clone into two distinct major clusters, bolting clones with complete flowers whereas none bolting and incomplete bolting clones formed together the second major cluster with overlapping.

Therefore, the present work aimed at examine the chromosome aberrations and certain cytological markers (SAT chromosomes and secondary constrictions) and their relationships to the nucleoli in six garlic clones. Biochemical assessment of two izozymes (glutamate oxaloacetate transaminase \& esterase) and total protein was also included.

\section{Materials and Methods}

\section{Chromosomal analysis}

\subsection{Chromosomes preparations}

Cloves were germinated in tap water at room temperature and growing root tips in 1-2 cm length were collected from plants of six Egyptian or Chinese garlic clones (Baladi, Sids 40, AZO 3, EGA 2, EGA 3 and EGA 4) and pretreated in $0.05 \%$ colchicine at room temperature for three hours and directly fixed with Farmer's solution (absolute Ethyl alcohol and Glacial acetic acid $3: 1 \mathrm{v} / \mathrm{v}$ ) for $24 \mathrm{~h}$ and kept in $70 \%$ ethanol at $4^{\circ} \mathrm{C}$. Roots were hydrolyzed using $1 \mathrm{~N} \mathrm{HCl}$ at $60^{\circ} \mathrm{C}$ for six minutes. Acetocarmine-squashed root tips were examined and then metaphase plates with well-spread chromosomes were chosen [11].

\subsection{Cytological examinations}

Chromosomal aberrations (gaps i.e., non-stained region of chromosome, chromatid breaks, centromeric attenuation and end-to-end association) were scored and calculated at hundred metaphase cells per clone. Good metaphase spreads were microphotographed using SIS computer program (version 4) with CCD camera (Olympus C-4040). The cells showed different types of chromosomal aberration were recorded as percentages of the total abnormal cells. To study the garlic SATchromosomes, percentage of cells contained SAT-chromosomes and nucleoli at chromosome complement of six garlic clones were calculated in prophase and interphase [11].

\section{Biochemical assessment}

\subsection{Total proteins and enzymes extraction}

Banding pattern of certain enzymes of esterase (EST), glutamate oxaloacetate transaminase (GOT) and total protein were used to determine the genetical and biochemical variations among the six studied garlic clones. To study the isozyme profile, the newly growing leaves (approximately $10 \mathrm{~cm}$ long) of three bulbs (two individual cloves/ bulb) of each clone were crushed in liquid nitrogen.
Before electrophoretic analysis, total protein from crushed leaves was extracted using $0.5 \mathrm{ml}$ of protein extraction buffer [0.1 M Tris $\mathrm{HCl}+2 \mathrm{mM}$ EDTA $(\mathrm{pH} 7.8) ; 40 \%$ sucrose and 1 mg 1-1 bromophenol blue] to $1 \mathrm{~g}$ of the frozen powder. Enzymes were also extracted by adding $0.5 \mathrm{ml}$ extraction buffer $(0.25 \mathrm{M}$ sodium phosphate buffer ( $\mathrm{pH}$ 6.8) containing $40 \%$ sucrose and $1 \mathrm{mg} \mathrm{1-1}$ bromophenol blue) to $1 \mathrm{~g}$ of the frozen powder followed by centrifugation for $10 \mathrm{~min}$ at $10,000 \mathrm{rpm}$ and $40 \mathrm{C}$. Sixty microliters of the supernatant were loaded directly onto polyacrylamide gel [ ].

\subsubsection{Staining proteins and isozymes}

The gels were carefully removed from mold and stained for visualizing the isozyme and total protein profiles.

\subsubsection{Total protein}

acetic acid and gel fixing solution (20\% glycerol solution).

\subsubsection{Esterase}

Glutamate Oxaloacetate Transaminase (GOT)

\section{Results and discussion}

\section{Cytological analyses}

\subsection{Chromosomal aberrations}

Data in Table (1) showed different percentages of some chromosomal aberrations at metaphase in cells of the six examined garlic clones (Baladi, Sids 40, AZO 3, EGA 2, EGA 3 and EGA 4 clones). The percentage of chromosome or chromatid gaps had considerable difference among the six studied clones. High percentage of gap (15\%) was observed in EGA 2 clone while EGA3 clone exhibited low percentage (5\%). Likewise, chromatid break ranged from $1 \%$ (Sids 40, EGA 3 and EGA 4) to $6.5 \%$ (EGA 2). The percentage of centromeric attenuation also varied among the six studied clones. It ranged from $1 \%$ (Baladi, AZO3 and EGA3) to 6\% (EGA 2). Similarly, end-toend association ranged from $1 \%$ to $3 \%$. Some types of these aberrations are shown in Figure (1).
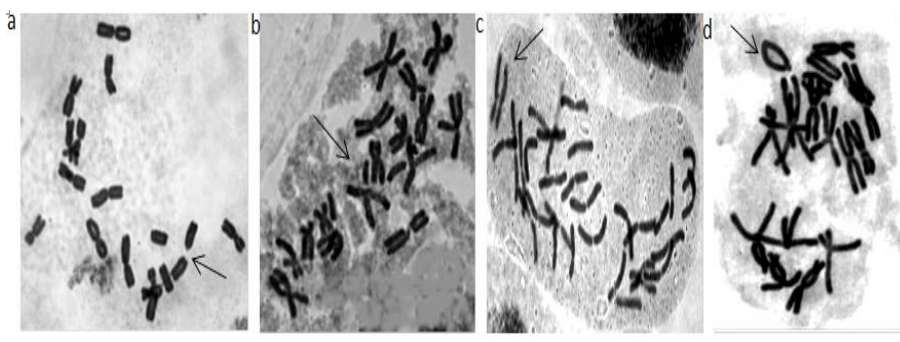

Figure (1): Metaphase cells of studied garlic clones showing different chromosomal aberrations; a: chromosome gap; b: chromatid break; c: centromeric attenuation; d: end-to-end association.

In the present work, types of structural chromosomal aberrations were scored in all six garlic clones. Some of these clones were from Chinese and the others from Egyptian origin. EGA2 clone (Chinese) exhibited the highest percentages of chromosomal aberrations. Chromosomal gap (non-stained region of chromosome), chromatid deletion, centromeric 
attenuation and end to end fusion were the most visible types of aberrations. Sometimes, these types of chromosomal aberrations were known as biomarkers of environmental pollution [28] and explained as a direct action of transposons [29]. Several large deletions $(\geq 100 \mathrm{~kb})$ were identified in Arabidopsis after excision during Ac-Ds transposition [30]. Examined cells in this study showed centromeric attenuation which may reveal the effect of transposons on cohesion complexes of mitotic chromosomes. Helmey and Anwar [9] concluded that one of the very important sources of genetic variation in garlic clones may be due to the preserved chromosomal aberrations. Transposons might be considered as the internal genomic elements that autonomously or non-autonomously mobilize to induce structural aberrations. Sister chromatids are held together by multi-subunit complexes called cohesions. Disruption of cohesion can lead to genome instability, such as aneuploidy, defects in DNA repair, and chromosomal translocations [31]. Mutations in cohesions have also been shown to result in an increased distance between sister centromeres [31]. Therefore, accumulation of these minor and major changes throughout apomictic asexual propagation has continuously occurred.

Table (1): Percentages of different chromosomal aberrations in the six studied garlic clones.

\begin{tabular}{|c|c|c|c|c|c|}
\hline Clones & Normal & $\begin{array}{l}\mathrm{Ga} \\
\mathrm{p}\end{array}$ & $\begin{array}{l}\text { Chromatide } \\
\text { breaks }\end{array}$ & $\begin{array}{l}\text { Centromeric } \\
\text { attenuation }\end{array}$ & $\begin{array}{l}\text { End- } \\
\text { to-end } \\
\text { associ } \\
\text { ation }\end{array}$ \\
\hline Baladi & $88 \%$ & $\begin{array}{l}6.5 \\
\%\end{array}$ & $3.5 \%$ & $1 \%$ & $1 \%$ \\
\hline Sids 40 & $82 \%$ & $\begin{array}{l}8.5 \\
\%\end{array}$ & $1 \%$ & $5.5 \%$ & $3 \%$ \\
\hline AZO 3 & $86.5 \%$ & $6 \%$ & $4.5 \%$ & $1 \%$ & $2 \%$ \\
\hline EGA 2 & $70 \%$ & $\begin{array}{l}15 \\
\%\end{array}$ & $6.5 \%$ & $6 \%$ & $2.5 \%$ \\
\hline EGA 3 & $92 \%$ & $5 \%$ & $1 \%$ & $1 \%$ & $1 \%$ \\
\hline EGA 4 & $86.5 \%$ & $6 \%$ & $1 \%$ & $4.5 \%$ & $2 \%$ \\
\hline
\end{tabular}

\subsection{SAT-chromosomes with Secondary constrictions}

According to the presence and number of SAT-chromosomes with secondary constrictions (SC), the examined cells of each studied garlic clones were divided into four categories as shown in Table (2). These 4 categories were calculated as percentages of cells with only one SAT-chromosome (category I), with two (category II), with three (category III) and with four SAT chromosomes (category IV). Sids 40 and EGA 4 clones exhibited category I, while Baladi, AZO 3 and EGA 3 clones showed category IV. Only one clone (EGA 2) exhibited category II. Category III had the lowest percentage at all examined garlic clones when compared with the other three categories. Different SAT-chromosome categories are shown in Figure (2a-d).
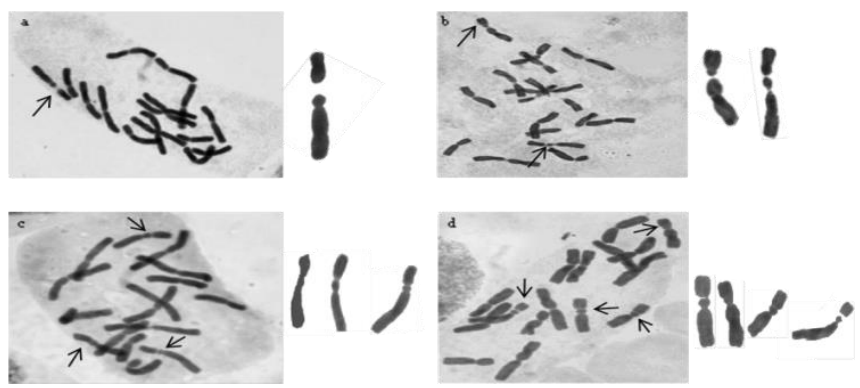

Figure (2): Normal metaphase plates of garlic cells showing a: cell type with SAT-chromosome category1, b: a type of cells in category 2, c: a cell with category 3 and d: a cell in category 4 . SAT-chromosomes are indicated.

Table (2): Percentages of cells contained four SAT chromosome categories of six garlic clones.

\begin{tabular}{lcccc}
\hline \multirow{2}{*}{ Clone } & \multicolumn{5}{c}{$\%$ of cells contained Sat- chromosomes } \\
& \multicolumn{5}{c}{ Category } & Category & Category & Category \\
& I (1SAT) & II (2 SAT) & 3 (3 SAT) & 4 (4 SAT) \\
\cline { 2 - 5 } & - & 10 & 15 & 75 \\
\hline Baladi & 95 & 5 & - & - \\
Sids 40 & - & - & 20 & 80 \\
AZO 3 & 10 & 90 & - & - \\
EGA 2 & & 7 & 8 & 85 \\
EGA 3 & 92 & 8 & - & - \\
EGA 4 & & & & \\
\hline
\end{tabular}

\subsection{Number of nucleoli at interphase and prophase}

In the studied six garlic clones, data in Table (3) showed that the maximum number of visible nucleoli was four at interphase while it was three at prophase with variable percentags. At interphase and prophase, both Sids 40 and EGA 4 clones had one nucleolus (more than $90 \%$ of examined cells). Baladi, AZO 3 and EGA 3 clones had either three or four nucleoli at prophase and two or three nucleoli at interphase. EGA 2 clone had two nucleoli at both interphase and prophase. No cells with four nucleoli were observed at the prophase of the studied clones. The micrographs of nucleoli at both interphase and prophase in the six studied garlic clones are shown in Figure (3).

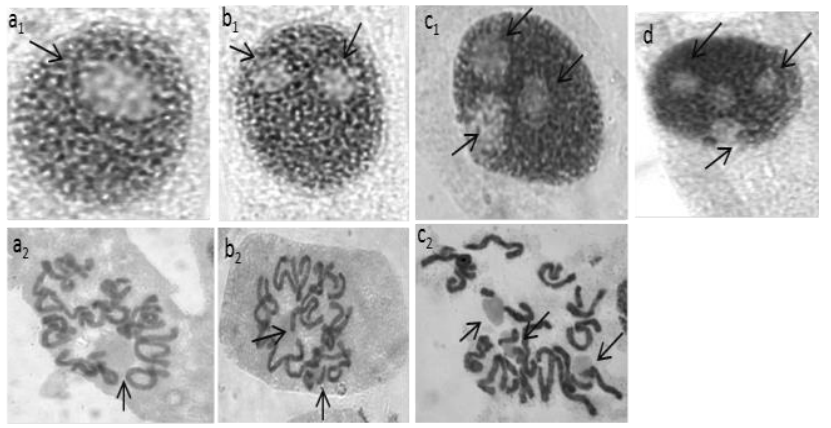

Figure (3): The nucleoli at both prophase $\left(a_{1}, b_{1}, c_{1}\right.$ and d) and interphase $\left(a_{2}, b_{2}\right.$ and $\left.c_{2}\right)$ of studied six garlic clones. $a_{1,2}$ : cells showing one nucleoli (arrow), $\mathrm{b}_{1,2}$ : cells with two nucleoli (arrows), $\mathrm{c}_{1,2}$ : cells have three nucleoli (arrows) and $\mathrm{d}$ : interphase cell showing four nucleoli (arrows).

It was known that mitotic cells of garlic plants have two SAT chromosome (SC) pairs (no.6 and 7). Otherwise, the examined cells even within the same root showed four different SAT chromosome categories with different percentages and approximately distributed in all chromosome pair. These data are in accordance with those formerly reported [3-11, 32 and 33] Four different nucleoli attached-chromosomes (pair nos. 5, 6, 7 and 8) were determined during meiotic drive of a flowering garlic clone [7]. In addition, they also reported that these four chromosome pairs have associated in a chain or ring configurations during meiotic division. It could be determined 
that these aberrations caused the variations in the position and size of these satellites along with chromosomes nos,5, 6, 7 and 8 . The secondary constrictions may be involved in the nucleolus organization; hence the intra and inter-individual variation in a number and size of secondary constrictions could be due to the shifting of nucleolar organizer in the chromosome arm brought by deletion and unequal translocation or inversion [35]. The variation in the size of the secondary constrictions probably reflects that of the nucleoli. Actually, the size of the nucleoli varied greatly within the same cell as did that of the secondary constrictions [13]. Miller, and Brown [14] and Elsevier and Raddle [34], concluded that the size of the secondary constrictions correlated positively with the redundancy of the rRNA genes. The maximum number of nucleoli per cell should correspond to the number of NORs [36 \& 37]. The numbers of nucleoli at either interphase and prophase ranged from one to three. Sometimes, interphase might possess 4 . The relationship between the number of nucleoli and the number of SAT and SC bearing chromosomes could be approved. Likewise, there is a strong relationship between chromosomal aberrations types and the number of both NORs and also satellite position in SAT chromosomes. Recent and advanced techniques may help to clarify this problem.

Table (3): Percentage of interphase and prophase cells contained nucleoli of six garlic clones.

\begin{tabular}{|c|c|c|c|c|c|c|c|}
\hline \multirow{3}{*}{ Clone } & \multicolumn{7}{|c|}{$\%$ of cells contained nucleoli } \\
\hline & \multicolumn{4}{|c|}{ Interphase } & \multicolumn{3}{|c|}{ Prophase } \\
\hline & $\begin{array}{c}\text { One } \\
\text { nucleoli }\end{array}$ & $\begin{array}{c}\text { Two } \\
\text { nucleoli }\end{array}$ & $\begin{array}{c}\text { Three } \\
\text { nucleoli }\end{array}$ & $\begin{array}{c}\text { Four } \\
\text { nucleoli }\end{array}$ & $\begin{array}{c}\text { One } \\
\text { nucleoli }\end{array}$ & $\begin{array}{c}\text { Two } \\
\text { nucleoli }\end{array}$ & $\begin{array}{c}\text { Three } \\
\text { nucleoli }\end{array}$ \\
\hline Baladi & 2 & 8 & 25 & 65 & 12 & 68 & 20 \\
\hline Sids 40 & 97 & 3 & - & - & 96 & 4 & - \\
\hline AZO 3 & 3 & 7 & 20 & 70 & 2 & 66 & 32 \\
\hline EGA 2 & 7 & 90 & 3 & - & 26 & 74 & - \\
\hline EGA 3 & 5 & 15 & 30 & 50 & 14 & 52 & 34 \\
\hline EGA 4 & 94 & 6 & - & - & 98 & 2 & - \\
\hline
\end{tabular}

\section{Biochemical studies}

\subsection{Total protein analyses}

SDS-PAGE analysis was carried out on six cloves of each studied garlic clones (Sids 40, AZO 3, Baladi, EGA 2, EGA 3 and EGA 4). The banding patterns of total protein were shown in Figure (4). The obtained data indicated that three monomorphic bands ( $\mathrm{a}, \mathrm{b}$ and $\mathrm{c}$ ) were found in all tested cloves. There were no banding polymorphism in total protein profiles either between or within the studied six garlic clones.

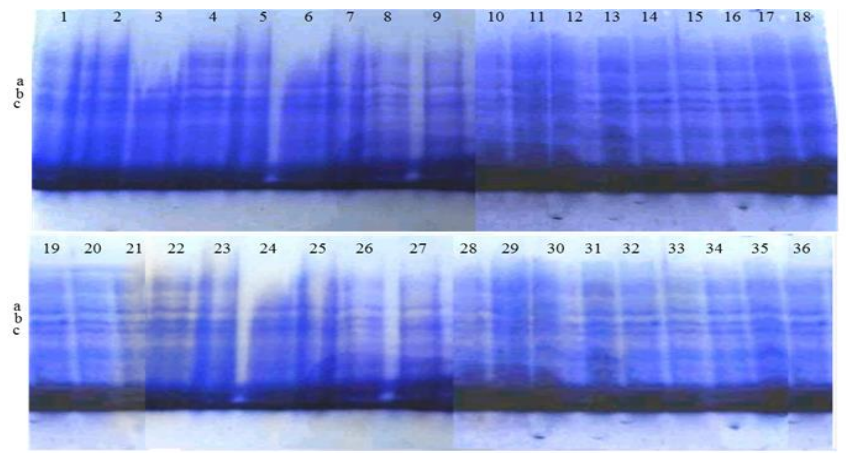

Figure (4): Electrophoretic band pattern of total protein of in 6 cloves of each studied garlic clone. 1 through 6 refer to: Sids 40 clone, 7 through 12 refer to: AZO 3 clone, 13 through 18 refer to: Baladi clone, 19 through 24 refer to EGA 2 clone, 25 through 30 refer to: EGA 3 clone and 31 through 36 refer to EGA 4 clone, respectively.

\section{GOT isozyme}

As shown in Figure (5), only two monomorphic bands (a and b) were produced in 36 cloves (6 cloves/bulb) of the six garlic clones. The banding pattern of GOT clearly revealed that polymorphic bands were absent.

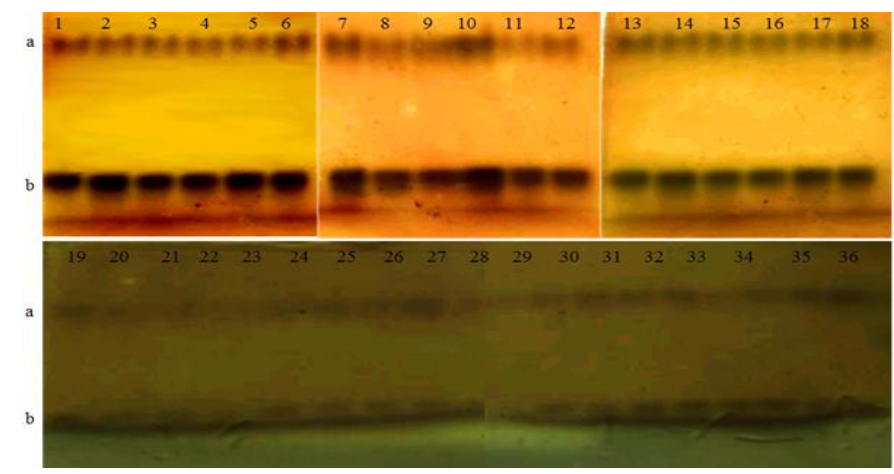

Figure (5): Electrophoretic pattern of GOT isozyme of six cloves in studied six garlic clones. 1 through 6 refer to: Sids 40, 7 through 12 refer to: AZO 3, 13 through 18 refer to: Baladi, 19 through 24 refer to: EGA 2, 25 through 30 refer to: EGA 3 and 31 through 36 refer to: EGA 4, respectively.

\section{3. Esterase isozyme analysis}

Isozyme banding pattern of esterase was studied also in the six garlic clones. Electrophoretic banding patterns of esterase are shown in Figure (6). One monomorphic band named (a) was observed while banding polymorphism either between or within the studied six garlic clones was not found.

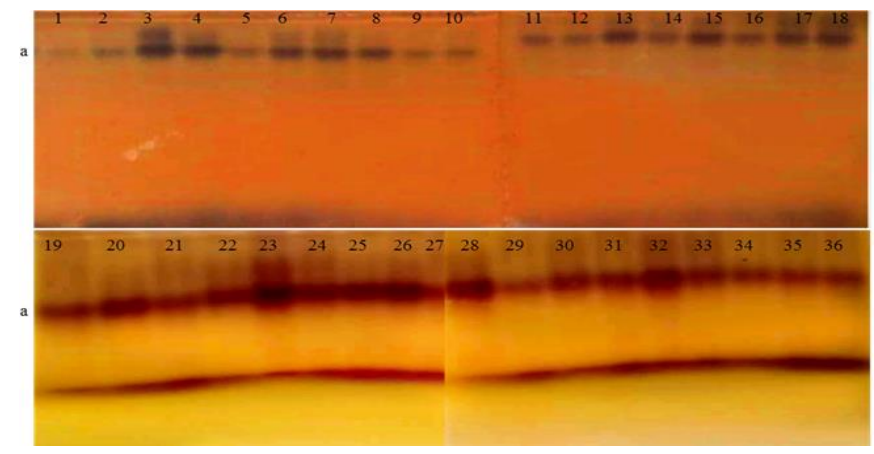

Figure (6): Electrophoretic pattern of esterase isozyme in six cloves of studied six garlic clones. 1 through 6 refer to: Sids 40, 7 through 12 refer to: AZO 3, 13 through 18 refer to: Baladi, 19 through 24 refer to: EGA 2, 25 through 30 refer to: EGA 3 and 31 through 36 refer to: EGA 4, respectively.

Total protiens and isozymes are prevailing tools for detecting genetic variability within and between populations of plants and animals. Therefore, total protiens and two different isozymes (esterase and glutamate oxaloacetate transaminase) (glutamate 
oxaloacetate transaminase and esterase) were used to define the genetical variation among the cloves of studied garlic clones in the present work. Analyzing the banding pattern of the total protien, GOT and esterase isozyme showed no differences amongst all studied clones. This finding is in covenant with the results of Elmamlouk et al. [3] who reported that the banding pattern of esterase and GOT were similar in all five garlic genotypes. Distinct ecotypes of bolting and non-bolting Bulgarian garlic clones was identified using the isozyme components of esterase [23]. A variability of esterase patterns in the winter ecotype clones, expressed by the presence or absence of Est-2. However, all summer ecotype clones have identical isoesterase spectra. Consequently, the suitability of isozyme markers for an intended plant study has to be tested in advance as reported by Klaas and Friesen [38]. The main disadvantages of protein markers are influenced by environmental conditions [39].

\section{Conclusion}

It could be concluded that one of the very important sources of genetic variation in garlic clones may due to the conserved chromosomal aberrations. A strong relationship was observed between existence of the structural chromosomal aberrations and numbers and position of some cytological markers such as satellites (SAT), secondary constrictions (SC) and nucleoli. In the present work, the relationship between the assessed biochemical markers (total protein or izsozymes (isozymes), GOT and esterase) and the scored chromosomal aberrations couldn't be proved. Additional studies on garlic are nearby regarding the variation even at individual level. Also, some molecular cytogenetic techniques should be examined on garlic to detect these complicated relations.

\section{References}

[1] Collins, J. L. and Kerns, K. R. Mutations in the pineapple. Jour. Heredity, 1938, 29: 163-172.

[2] Koul, A. K., Gohil, R. N. and Langer, A. Prospects of breeding improved garlic in the light of its genetic and breeding systems. Euphytica, 1979, 28: 457464.

[3] El-Mamlouk, E. A-K., Ata, A. M., Mahmoud, M. A-H., Foly, H. M. and Allam, H. Z. Cytological features and isozymes profile of some Allium sativum L. (garlic) genotypes cultivated in Egypt, Minia Journal of Agricultural Research and Development, 2002, 22: 1420-1440.

[4] Ata, A. M. Constitutive heterochromatin diversification of two Allium species cultivated in Egypt, Proc. Afr. crop sci. conf., 2005, 7: 225-231.

[5] Osman, S. A., Ata, A. M. and Gad, El-Hak S. E. Morphological germination bolting and cytogenetical characteristics of fourteen promising garlic genotypes. Proc. Afr. Crop Sci. Conf., 2007, 8: 2005-2012.

[6] Ata, A. M. and Osman, S. A. Gametogenesis of two garlic clones selected from Egyptian indigenous forms. African Crop Science Conference Proceedings, 2009, 9: 483-487.

[7] Anwar, G. M. and Ata, A. M. Chromosome association of two flowering garlic clones. Indian Journal of plant Sciences, 2017, 6: 52-58.

[8] Mahmoud, M. A-H., Ata, A. M., Anwar, G. M., Tawfeek, A-R. and Dakhly, O. F. Studies of some cytological features of garlic (Alliium sativum L.) clones cultivated in Egypt. Egypt. J. Plant Breed., 2017, 21: 800-819.

[9] Helmey, R. K., and Anwar, G. M. Chromosomal aberrations and Ac/Ds transposition in Garlic. Chromosome Botany, 2018, 12: 72-76.

[10] Anwar, G. M., Mahmoud, M. A-H., Ata, A. M., Ragab A-K. Ragab and Bakry H. S. H. Studies of molecular variation sources using RAPD and SSR markers in two garlic clones. J. Mod. Res., 2020, 2: 115-122.

[11] Ata, A. M., Anwar, G. M., Mahmoud, M. A-H., Ragab, A-K. R., and Bakry H. S. H. Variation of karyotype formula, and asymmetry between individual plants of garlic and its relationship with AC transposon, Minia J. of Agric. Res. \& Develop., 2020, 40:1-19.
[12] Sanai, S. S. and Davis, G. N. Karyotype analysis of some Allium species. J. Amer. Soc. Hort. Sci., 1967, 95: 102-105.

[13] Sato, Y., Izumiya, K., Sato, H., Cowell, J. L. and Manclark, C .R. Aerosol infection of mice with Bordetella pertussis. Infect. Immun., 1980, 29: 261-266.

[14] Miller, L. H. and Brown, H. W. The serologic diagnosis of parasitic infections in medical practice. Ann. intern. Med., 1969, 71: 983-992.

[15] Hizume, M., Tanaka, A., Yonezawa, Y. and Tanaka, R. A technique for Cbanding in Vicia faba chromosomes. Japan. Genetics, 1980, 55: 301-305.

[16] Acquaah, G.: Practical protein electrophoresis for genetic research. Dioscorides Press, Portland., 1992.

[17] Siqueira, W. J., Medina, F., Lisbao, R. and Fornasier, J. Morphological and electrophoretic characterization of garlic clones (Allium sativum). Bragantia, 1988, 44: 357-374.

[18] Chomatová, S., Turkova, V. and Klozova, E. Protein complex and esterase isoenzyme patterns of Allium sativum L. cultivars and clones-regenerants. Biologia plant, 1990, 32: 321-331.

[19] Madhavi, D. L., Prabha, T. N., Singh, N. S. and Patwardhan, M. V. Biochemical studies with garlic (Allium sativum) cell cultures showing different flavour levels. J. Science Food and Agriculture, 1991, 56: 15-24.

[20] Pooler, M. R. and Simon, P. W. Characterization and classification of isozyme and morphological variation in a diverse collection of garlic clones. Euphytica, 1993, 68: 121-130.

[21] Maass, H. I. and Klaas, M. Infraspecific differentiation of garlic (Allium sativum L.) by isozyme and RAPD markers. Theor. Appl. Genet., 1995, 91: 8997.

[22] Zeidler, M. Genetic variability among populations of Allium carinatum subsp. Carinatum. Thaiszia, 1999, 9: 81-90.

[23] Cholakova, N. Application of esterase isozymes for garlic ecotype identification. Biologia Plantarum (Prague), 2000, 43: 445-446.

[24] El-Aref, H. M. An effective method for generating somaclonal variability in Egyptian garlic (Allium sativum L.). Proceeding of the 3rd Scientific Conf. of Agriculture Sci., Fac. of Agric., Assiut Univ., Assuit, Egypt, 20-22 October, 2002, 479-495.

[25] Anwar, G. M., Ata, A. M., Mahmoud, M. A-H., Tawfeek, A-R. and Dakhly, O. F. morphological and biochemical assessment of sixteen garlic clones cultivated in Egypt. Egypt., J. Plant Breed., 2017, 21:820-835.

[26] yossif, A. M. Molecular studies on Mentha spp. M. Sc. Thesis, Faculty of Agriculture, Minia University, Egypt, 2018.

[27] Tanksley, S. D. and Orton, T. J. Isozymes in plant genetics and breeding. Part A (eds.), S. D. Tanksley and Orton, T. J., Elsevier Sci. Publisher B. V., New York, pp. 500, 1986.

[28] Firbas, P and Amon, T. Chromosome damage studies in the onion plant Allium cepa L., Cytologia, 2014, 67: 25-35.

[29] Zhang, J. and Peterson, T. Genome rearrangements by nonlinear transposons in maize. Genetics, 1999, 153: 1403-1410.

[30] Page, D. R., Kohler, C., da Costa-Nunes, J. A., Baroux, C. and Moore, J. M. Entrachromosomal excision of a hybrid Ds element induces large genomic deletions in Arabidopsis. Proc. Natl. Acad. Sci. USA, 2004, 101: 2969-2974.

[31] Brooker, A. S. and Berkowitz, K. M. The roles of cohesions in mitosis, meiosis, and human health and disease. Methods Mol Biol., 2014, 1170: 229 266.

[32] Helmy, R. K. exploration of karyotype differentiation in cells of a garlic clone and its derivative filial plants. Egypt. J. Bot., 2020, 60: 837-853.

[33] Yüzbaşioğlu, D. and Ünal, F. Karyotyping, c- and NOR banding of Allium sativum L. (Liliaceae) cultivated in Turkey. Pakistan Journal of Botany, 2004 36: 343-349.

[34] Elsevier, S. M., Ruddle, F. H., Location of genes coding for 18 s and $28 \mathrm{~s}$ ribosomal RNA within the genome of Mus rnusculus. Chromosoma (Berl.), 1975, 52: 219-228

[35] Verma, R. C. and Raina, S.N. Cytogenetics of Crotalaria II. Male meiosis in 8 species of Crotalaria, Cytologia, 1981, 45: 297-306.

[36] Sato, D. and Asano, A., Basikaryotype analysis in Nothoscordum fragrans $(2 \mathrm{n}=19)$. Bot. Mag. Tokyo, 1951, 64: 209-215.

[37] Nicoloff, H., Anatassova-Kristeva, M., Konzel, G., Rieger, R. The behavior of nucleolus organizers and their ribosomal gene content. Chromosoma (Berl.), 1977, 62:103-109.

[38] Klaas, M. and Friesen, N. Molecular markers in Allium In: H. D. Rabinowitch and L. Currah (eds.). Allium crop science: recent advances. CAB Int. Wallingford, UK., 2002, p. 159-185.

[39] Weeden, N. F. Distinguishing among white seeded bean cultivars by means of allozyme genotypes. Euphytica, 1984, 33: 199-208. 